\title{
IMPLEMENTASI PROGRAM PERENCANAAN PERSALINAN DAN PENCEGAHAN KOMPLIKASI (P4K) DI PUSKESMAS PONED KABUPATEN PEKALONGAN
}

\author{
Hilda Prajayanti ${ }^{1}$, Maslikhah ${ }^{2}$, Ida Baroroh $^{3}$ \\ hi317a.praja@yahoo.co.id \\ Akademi Kebidanan Harapan Ibu Pekalongan \\ Jl. Sriwijaya No. 7 Kota Pekalongan \\ Telp 085200072426
}

\begin{abstract}
Abstrak
Keberhasilan Pembangunan Kesehatan dapat dilihat dari berbagai indikator yang digunakan untuk memantau derajat kesehatan sekaligus sebagai evaluasi keberhasilan pelaksanaan program. Untuk mengidentifikasi masalah dan hambatan tersebut perlu dilakukan analisis situasi dan kecenderungan di masa mendatang. P4K adalah program yang dicanangkan dalam upaya mempercepat penurunan angka kematian ibu dengan cara memantau, mencatat serta menandai setiap ibu hamil. Dengan begitu diharapkan setiap ibu hamil sampai dengan bersalin dan nifas dapat dipantau oleh masyarakat dan tenaga kesehatan untuk mendapatkan pelayanan yang sesuai standar sehingga proses kehamilan dan persalinan sampai dengan nifas termasuk rujukannya dapat berjalan dengan aman dan selamat, tidak terjadi kesakitan dan kematian ibu serta bayi yang dilahirkan selamat dan sehat. Tujuan Penelitian yaitu Menjelaskan Implementasi P4K di Puskesmas PONED Kabupaten Pekalongan. Desain Penelitian yang digunakan yakni desain penelitian deskriptif yang bersifat kualitatif. Subjek Penelitian meliputi informan utama yaitu 9 bidan pelaksana di Puskesmas PONED Wilayah kerja Dinas Kesehatan Kabupaten Pekalongan dan informan triangulasi yang terdiri dari Kasie Kesga Dinas Kesehatan Kabupaten Pekalongan, Kepala Puskesmas, serta kader kesehatan pelaksana P4K. Pengumpulan data dilakukan melalui wawancara mendalam dan analisis dengan analisis isi.

Hasil Penelitian menunjukkan Kegiatan implementasi P4K yang belum berjalan adalah donor darah dan tabulin, penyebabnya adalah karena banyak ibu hamil belum mengetahui golongan darah anggota keluarganya dan masih mengandalkan Jaminan Kesehatan dari pemerintah. Tidak ada aturan yang jelas dalam menggalang tabulin. Bidan sudah aktif melibatkan kader dalam menjalankan P4K, namun tidak semua mendapatkan pelatihan dan informasi dari Dinas Kesehatan. Sosialisasi yang dilaksanakan oleh DKK kepada bidan wilayah dan kader hanya dilaksanakan setiap 1 tahun sekali dalam bentuk penyegaran dan hanya diwakili beberapa orang. Kondisi masyarakat dengan tingkat ekonomi masyarakat dalam strata menengah dan menengah kebawah yaitu buruh dan dagang tidak mempengaruhi kegiatan P4K karena banyaknya jaminan kesehatan yang diandalkan oleh masyarakat
\end{abstract}

Kata Kunci : Implementasi Program, P4K, Puskesmas PONED.

\section{Pendahuluan}

Keberhasilan Pembangunan Kesehatan dapat dilihat dari berbagai indikator yang digunakan untuk memantau derajat kesehatan sekaligus sebagai evaluasi keberhasilan pelaksanaan program. Derajat kesehatan masyarakat dipengaruhi oleh banyak faktor, tidak hanya berasal dari sektor kesehatan seperti pelayanan kesehatan dan ketersediaan sarana dan prasarana kesehatan, melainkan juga dipengaruhi faktor ekonomi, pendidikan, lingkungan sosial, keturunan, dan faktor lainnya. Pada prinsipnya pembangunan kesehatan telah menunjukkan suatu keberhasilan dengan meningkatnya derajat kesehatan masyarakat, walaupun masih dijumpai berbagai masalah dan hambatan yang akan mempengaruhi pelaksanaan pembangunan kesehatan. Untuk mengidentifikasi masalah dan hambatan tersebut perlu dilakukan analisissituasi dan kecenderungan dimasa mendatang. ${ }^{2}$

Program Perencanaan Persalinan dan Pencegahan Komplikasi (P4K) adalah suatu program yang dicanangkan dalam upaya mempercepat penurunan angka kematian ibu dengan cara memantau, mencatat serta menandai setiap ibu hamil. Program ini dilaksanakan oleh tenaga kesehatan dibantu kader dan tokoh masyarakat. dengan menempelkan stiker berisi nama, tanggal taksiran persalinan, penolong persalinan, tempat persalinan, pendamping persalinan, transportasi dan calon pendonor darah pada rumah yang di dalamnya terdapat ibu hamil. Dengan 
begitu diharapkan setiap ibu hamil sampai dengan bersalin dan nifas dapat dipantau oleh masyarakat sekitar dan tenaga kesehatan untuk mendapatkan pelayanan yang sesuai standar sehingga proses persalinan sampai dengan nifas termasuk rujukannya dapat berjalan dengan aman dan selamat, tidak terjadi kesakitan dan kematian ibu serta bayi yang dilahirkan selamat dan sehat. ${ }^{7,9}$

\section{Metode Penelitian}

Penelitian ini menggunakan desain penelitian deskriptif yang bersifat kualitatif yang bermaksud untuk memahami fenomena tentang apa yang dialami oleh subjek penelitian yaitu bidan pelaksana $\mathrm{P} 4 \mathrm{~K}$ yang meliputi kegiatan pemberdayaan masyarakat dalam kegiatan P4K yaitu kegiatan notifikasi, donor darah, transportasi dan tabulin.

Pengumpulan data menggunakan pendekatan cross sectional, yaitu pengumpulan data dilakukan sekaligus pada suatu saat ${ }^{18}$. Jenis data menggunakan data primer dan sekunder. Pengumpulan data primer dilakukan dengan teknik wawancara mendalam untuk mendapatkan data tentang kegiatan pemberdayaan masyarakat oleh bidan untuk mendukung $\mathrm{P} 4 \mathrm{~K}$, sumberdaya, karakteristik agen pelaksana, sikap para pelaksana, komunikasi dan kondisi ekonomi, sosial dan politik. Wawancara dilakukan menggunakan pedoman wawancara dibantu alat tulis dan tape recorder. Data Sekunder didapat dengan cara observasi untuk mendapatkan data-data dari laporan pelaksanaan $\mathrm{P} 4 \mathrm{~K}$ baik melalui PWS-KIA, Kohort dan Laporan Kegiatan P4K.

Subjek penelitian ini adalah bidan pelaksana P4K yang merupakan informan utama yaitu sebanyak 9 bidan pelaksana di Puskesmas PONED Wilayah kerja Dinas Kesehatan Kabupaten Pekalongan, sedangkan informan Triangulasi terdiri dari Kasie Kesga Dinas Kesehatan Kabupaten Pekalongan, Kepala Puskesmas, serta kader kesehatan pelaksana P4K.

\section{Hasil dan Pembahasan}

a. Kegiatan Pemberdayaan Masayarkat oleh bidan untuk mendukung P4K

Kegiatan pemberdayaan masyarakat untuk mendukung $\mathrm{P} 4 \mathrm{~K}$ terdiri dari kegiatan notifikasi (pencatatan dan penandaan ibu hamil), penggalangan donor darah, tabulin dan dasolin serta penggalangan sarana transportasi.

1) Pencatatan dan penandaan ibu hamil (Notifikasi)

Sebagian besar informan utama menyatakan bahwa kegiatan pencatatan dan penandaan ibu hamil (notifikasi) dilakukan oleh bidan dan kader. Dalam hal ini bidan membantu medampingi, mengisi KMS dan mendapatkan laporan dari kader. Hal tersebut sesuai dengan pernyataan yang disampaikan oleh sebagian besar informan triangulasi yang menyatakan bahwa dari kegiatan yang dilakukan dalam mendukung program $\mathrm{P} 4 \mathrm{~K}$ yaitu penandaan, pemantauan dan pemasangan stiker dilakukan oleh kader. Pernyataan informan penelitian terdapat pada kotak 2

Kotak 2

"Ya Semua dilakukan kader, kalau ada kesulitan dibantu bidan. Bidan itu hanya memantau" (Inf K6)

"Penandaan dan pemantauan dilakukan kader jika ada waktu maka bidan mendampingi kader" (Inf K3)

Hasil penelitian menunjukkan adanya persamaan informasi antara informan utama dengan informan triangulasi yang menyatakan bahwa kegiatan penandaan ibu hamil (notifikasi) dilakukan oleh kader, bidan hanya mengecek pada saat posyandu. Hal ini terjadi karena yang bersinggungan langsung dengan masyarakat adalah kader, sehingga kontak dengan masyarakat juga banyak dilakukan oleh kader daripada bidan. Namun jika ada kesulitan tetap difasilitasi oleh bidan. 
Implementasi operasional di tingkat desa menyatakan bahwa bidan bersama kader melakukan kontak dengan ibu hamil, suami dan keluarga untuk sepakat dalam pemasangan stiker (notifikasi). ${ }^{9,11}$ Sesuai dengan perannya sebagai change agent maka setelah peran edukasional (penyampaian informasi) dilakukan maka bidan berperan dalam ketrampilan teknik untuk memberdayakan masyarakat melakukan kegiatannya secara mandiri. ${ }^{14}$

2) Penggalangan Donor Darah

Sebagian besar Informan utama menyatakan tidak banyak hambatan dalam notifikasi. Hambatan yang banyak disampaikan informan utama yaitu penggalangan donor darah dan tabungan ibu bersalin yang belum banyak diketahui manfaatnya. Pernyataan informan penelitian terdapat pada kotak 3

Kotak 3

"Banyak ibu hamil yang kurang memperdulikan donor darah....." (Inf B1)

"Tabulin tidak jalan karena ada jamkesmas, jamkesda dan jampersal ..." (Inf B8).

Hambatan yang banyak di sampaikan informan utama yaitu penggalangan donor darah dan tabungan ibu bersalin karena sudah mempunyai kartu jaminan kesehatan. Pernyataan informan tersebut terdapat pada kotak 4

Kotak 4

"Penggalangan donor darah karena takut....." (Inf B6)

"Jarang, paling hanya untuk donor darahnya..." ( Inf B5)

Hal ini sejalan dengan pernyataan sebagian besar informan triangulasi yaitu penggalangan donor darah belum bisa dilaksanakan dengan baik, bahkan 2 informan triangulasi menyatakan bahwa penggalangan donor darah sulit dilaksanakan karena susah mencari golongan darah yang sama dan banyak masyarakat yang tidak tahu golongan darahnya sendiri. Pernyataan informan penelitian terdapat pada kotak 5.

\section{Kotak 5}

"Ya paling Cuma donor darah yang susah mencari golongan darah yang sama bu." (Inf K7)

"Jarang, paling hanya untuk donor darahnya. kadang tidak tahu golongan darahnya sendiri" (Inf K5)

Penggalangan Donor Darah diperlukan untuk menjamin ketersediaan darah yang dikelola masyarakat dengan membentuk Pokja Donor Darah. ${ }^{2}$ Penggalangan relawan yang bersedia menjadi pendonor darah sewaktu-waktu diperlukan data dari masyarakat. Untuk itu sebelum dilakukan penggalangan donor darah, terlebih dahulu dilakukan identifikasi golongan darah ibu hamil serta seluruh penduduk desa sehingga seluruh penduduk dapat berpartisipasi menjadi calon pendonor. Walaupun reaksi yang ditunjukkan masyarakat beragam seperti hasil wawancara kepada informan yang menyatakan bahwa susah mencari golongan darah yang sama, namun penggalangan donor darah harus tetap dilakukan sebagai bentuk upaya pencegahan apabila terjadi komplikasi pada ibu hamil. Untuk mengatasi permasalahan tersebut maka identifikasi dilakukan pengecekan golongan darah di Puskesmas dan setidaknya ada pendonor dari keluarganya sendiri yang mempunyai golongan darah yang sama dan terbukti aman dari HIV/AIDS serta hepatitis. 
3) Tabulin (Tabungan Ibu

Bersalin)

Sebagian besar informan utama menyatakan bahwa tabulin tidak berjalan dikarenakan adanya jaminan kesehatan seperti BPJS, jamkesmas, jamkesda dan jampersal. Selain itu kebanyakan dari ibu hamil sudah mempunyai tabungan sendiri serta kurangnya kepercayaan terhadap keamanan uang jika disimpan oleh kader atau bidan. Pernyataan informan penelitian terdapat pada kotak 6

Kotak 6
"Tabulin tidak jalan karena ada jamkesmas,
jamkesda dan jampersal”(Inf B8)
“Tabulin tidak jalan, susah sekali. Sangat banyak
orang yang gak siap dengan program ini.
Karena biasanya orang yang gak mampu masih
mengandalkan BPJS...(Inf B9)

Hal ini sama seperti yang diungkapkan oleh informan triangulasi yang menyatakan bahwa tabulin tidak berjalan dikarenakan adanya jaminan kesehatan seperti BPJS, jamkesmas dan jampersal seperti yang dikutip pada kotak 7.

Kotak 7

"Tabulin tidak jalan karena ada BPJS dan Jamkesmas" (Inf K6)

Hasil penelitian menunjukkan adanya persamaan informasi antara informan utama dan triangulasi yang menyatakan bahwa tabulin tidak berjalan karena adanya jaminan kesehatan terutama BPJS dan jaminan persalinan maka masyarakat banyak yang mengandalkan jaminan kesehatan dari pemerintah tersebut, khususnya untuk masyarakat miskin.

TABULIN (Tabungan ibu bersalin) adalah upaya menyisihkan uang atau barang berharga (yang bisa diuangkan sewaktu-waktu) oleh ibu hamil yang disimpan oleh bidan desa atau pihak yang ditunjuk oleh masyarakat yang sewaktu-waktu dapat dipergunakan untuk biaya persalinan. Besar simpanan/nominal tergantung dari perkiraan biaya persalinan normal atau sesuai dengan kesepakatan. $^{2}$

Banyaknya jaminan kesehatan yang dikeluarkan oleh pemerintah seperti BPJS, jamkesmas, jamkesda dan jampersal yang sebetulnya ditujukan untuk masyarakat miskin ternyata membawa dampak yang kurang baik terhadap implementasi program kesehatan khususnya Program Perencanaan Persalinan dan Pencegahan Komplikasi (P4K), karena biaya kesehatan yang cukup tinggi di Indonesia membuat masyarakat hanya mengandalkan jaminan kesehatan tersebut. Upaya untuk memandirikan masyarakat terganjal banyaknya jaminan kesehatan yang bisa didapatkan dengan mudah. Terlebih lagi biaya ditanggung pemerintah sejak kehamilan yaitu pemeriksaan kehamilan atau ANC sebanyak 4 kali, pertolongan persalinan dan pelayanan nifas dengan biaya gratis yang ditanggung oleh pemerintah. Selain itu, jampersal tidak hanya berlaku di institusi pelayanan kesehatan pemerintah tetapi juga di institusi pelayanan kesehatan swasta yang mengikuti program jampersal.

b. Ukuran Dasar dan Tujuan

Ukuran dasar dan tujuan kebijakan yang dimaksudkan adalah tujuan dan sasaran program $\mathrm{P} 4 \mathrm{~K}$ yang direfleksikan dalam bentuk dokumen seperti regulasi dan garisgaris pedoman program yang menyatakan kriteria untuk evaluasi 
kinerja kebijakan $\quad$ P4K. ${ }^{11}$

Berdasarkan hasil wawancara pada informan utama dan triangulasi Sebagian besar menyatakan bahwa dalam pelaksanaan kegiatan $\mathrm{P} 4 \mathrm{~K}$ tidak ada aturan tertulis, yang ada hanya pedoman buku KIA. Sebagian besar informan triangulasi kader menyatakan tidak tahu dan belum pernah melihat pedoman pelaksanaan P4K, beberapa informan kader menyatakan hanya ada buku petunjuk pelaksanaan sosialisasi P4K. Pernyataan informan penelitian terdapat pada kotak 8

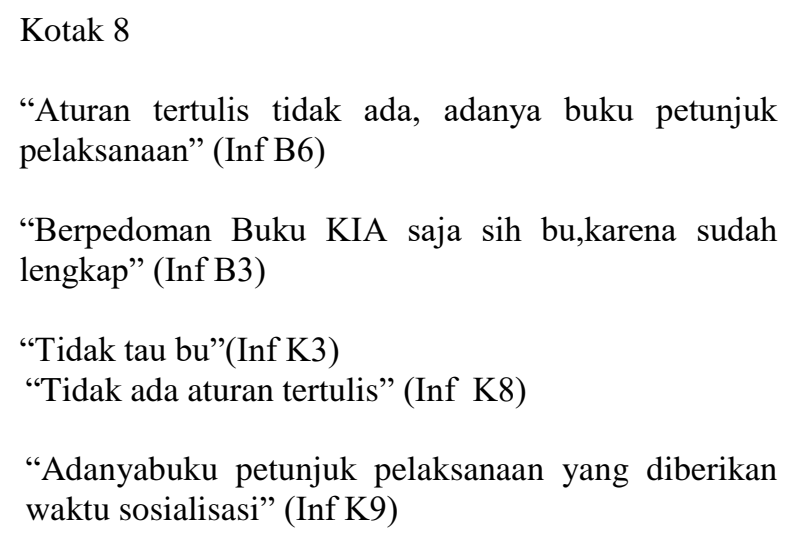

Hal ini tidak sesuai dengan teori yang ada bahwa suatu implementasi kebijakan hendaknya jelas tercantum dalam suatu regulasi atau pedoman program sehingga evaluasi kinerja kebijakan dapat dilakukan. ${ }^{11}$ Hasil penelitian tentang kegiatan untuk mendukung P4K ditemukan masalah dalam hal penggalangan tabulin dan donor darah. Tidak adanya aturan yang jelas tentang kegiatan pemberdayaan masyarakat dalam menggalang tabulin.

c. Sumberdaya

1) Sumberdaya Manusia

Sebagian besar informan utama menyatakan bahwa tenaga yang ada dalam memberdayakan masyarakat adalah bidan dan kader. Beberapa informan utama menyatakan bahwa selain bidan dan kader juga dibantu oleh Penyuluh Lapangan Keluarga Berencana (PLKB). Pernyataan tersebut terdapat pada kotak 9
Kotak 9

"Bidan yang memberdayakan kader. Kader ke masyarakat kadang dibantu PLKB..."(Inf B5)

"bidan dan kader di tiap posyandu sudah mengerti tugasnya walaupun belum ikut pelatihan" (Inf B7)

Hal ini sejalan dengan informasi dari seluruh informan triangulasi kader yang menyatakan bahwa tenaga bidan dan kader yang ada dalam mendukung kegiatan $\mathrm{P} 4 \mathrm{~K}$ sudah mencukupi.

Hasil penelitian menunjukkan adanya persamaan informasi antara informan utama dan triangulasi tentang sumberdaya dalam kegiatan pemberdayaan masyarakat adalah bidan dan kader. Hal ini sudah sesuai dengan konsep pemberdayaan masyarakat bahwa bidan telah melibatkan masyarakat yaitu kader dalam menjalankan program kesehatan sehingga hasil yang dicapai bisa maksimal. ${ }^{15}$ Namun kegiatan tabulin yang tidak berjalan tidak hanya dipengaruhi oleh faktor sumber daya manusia saja namun sumber daya yang lain ikut menunjang. Faktor dana dan fasilitas yang tidak memadai akan menghambat upaya pemberdayaan masyarakat dalam melaksanakan suatu kegiatan. Wirjana (2007) menyatakan bahwa suatu program akan dapat terlaksana secara efektif dan mencapai misinya diantaranya memerlukan sumberdaya manusia dan dana. Sumberdaya manusia yang ada harus mempunyai pengetahuan, ketrampilan dan sikap yang tepat sebagai pelaku. ${ }^{10}$

Dalam kegiatan pemberdayaan masyarakat khususnya dalam kegiatan P4K, bidan dan kader merupakan pelaku yang tepat karena bidan bergerak dalam bidang kesehatan dan kader sebagai perpanjangan tangan yang mengetahui sosial budaya 
masyarakat setempat sehingga dapat merangkul masyarakat dan memotivasi untuk ikut andil dalam kegiatan tersebut. Seperti hasil penelitian Azizah yang menyatakan bahwa pembinaan kader secara rutin akan dapat meningkatkan kinerjanya dalam memberdayakan masyarakat. ${ }^{10}$

2) Dana

Hasil wawancara mendalam didapatkan seluruh informan utama menyatakan bahwa dana yang diperoleh untuk memperlancar pelaksanaan $\mathrm{P} 4 \mathrm{~K}$ yaitu dari dana Bantuan Operasional Kesehatan (BOK). Mengenai bantuan dana, sebagian besar Informan triangulasi kader menyatakan bahwa bantuan dana dari puskesmas yang diperoleh hanya transport untuk ibu hamil. Pernyataan informan penelitian terdapat pada kotak 12 .

Kotak 12

"Bantuan kalau ada kelas ibu hamil itu ya transport untuk ibu hamilnya sendiri." (inf K3)

"Transport aja sih bu untuk ibu hamilnya" (Inf K5)

"Ada untuk ibu hamilnya dan biasanya dari puskesmas kalau ada kegiatan kelas ibu hamil kader yang ditempati juga dapat untuk mengganti snack saja sih bu...” (Inf K9)

Adanya persamaan informasi yang menyatakan bahwa dana berasal dari Puskesmas diambil dari dana BOK. Namun, dana khusus dalam upaya mendukung P4K tidak ada. Dana sangat diperlukan untuk menjalankan suatu kegiatan. Tanpa dana maka kegiatan tidak akan bisa berjalan dengan baik. Besar kecilnya dana yang ada mempengaruhi seberapa besar keberhasilan suatu program untuk dijalankan. Ketika sumberdaya manusia kompeten, namun kucuran dana tidak ada maka dapat menjadi penyebab ketidakberhasilan implementasi kebijakan. ${ }^{11}$

3) Fasilitas

Hasil wawancara mendalam didapatkan bahwa informan utama dan informan triangulasi kader menyatakan fasilitas yang selama ini mendukung kegiatan P4K seluruhnya dari bidan dan diperkuat dengan pernyataan informan triangulasi kader dan kepala puskesmas bahwa dari segi fasilitas untuk mendukung kegiatan P4K seluruhnya dari bidan pelaksana. Seperti terkutip pada pernyataan kotak 14 .

Kotak 14

“Biasanya dari bidan desa sendiri.” (inf K1)

"Kalau fasilitas sepenuhnya di handle sama bidannya masing-masing. Kalau dari puskesmas hanya ada rapat bidan dan kepala puskesmas, bidan selalu menyampaiakan permasalahanpermasalahan yang muncul di desa wilayah kerjanya. Untuk urun rembug bu untuk pemecahan masalahnya" (Inf KP)

Adanya persamaan informasi antara informan utama bidan dengan informan triangulasi kader dan kepala puskesmas untuk fasilitas yang selama ini mendukung kegiatan P4K seluruhnya dari bidan. Fasilitas (sarana dan prasarana) juga menjadi faktor penentu adanya keberhasilan suatu implementasi kebijakan. ${ }^{10}$ Untuk memperoleh perubahan perilaku yang efektif diperlukan faktor pendukung berupa sumberdaya dan fasilitas yang memadai yang digali dan dikembangkan dari masyarakat. Masyarakat harus mampu mengorganisasikan

komunitasnya untuk berperan dalam penyediaan fasilitas.

Sesuai hasil wawancara pada informan maka pengadaan fasilitas telah sesuai dengan teori fasilitas sarana dan prasarana. pemberdayaan masyarakat yang ada 
d. Karakteristik Pelaksanaan P4K

1) Supervisi

Hasil wawancara mendalam

didapatkan bahwa sebagian

besar informan utama

menyatakan ada supervisi 1

tahun sekali dari dinas

kesehatan walaupun dengan jadwal yang tidak menentu. Ada beberapa Bidan yang menyatakan rutin megadakan pembinaan setiap bulan atau saat pertemuan kader. Pernyataan informan penelitian terdapat pada kotak 15 .

\section{Kotak 15}

"Pengawasan dilakukan 1 tahun sekali dari dinas sih bu." (inf B2)

"Awal pelaksanaan rutin dilakukan oleh dinas bu. Terus jika ada masalah dikunjungi oleh dinas.Bidan supervisi tiap bulan..(Inf B7)

"Pembinaan 1 tahun sekali dari dinas. Bidan mengadakan pembinaan rutin bulanan setiap pertemuan kader..." (Inf B9)

\section{Sebagian besar informan \\ triangulasi kader menyatakan \\ bahwa supervisi dalam \\ mendukung program $\mathrm{P} 4 \mathrm{~K}$ \\ berasal dari bidan dan ada 1 \\ (satu) kader menyatakan pernah \\ 1 (satu) kali dinas kesehatan \\ melakukan supervisi dan jika \\ ada lomba saja melakukan \\ kunjungan. \\ Pernyataan tersebut terdapat pada Kotak 16}

\section{Kotak 16}

"Supervisi dinas langsung ke desa jika mau ada lomba kok ...." (inf K8)

" Kalo Bidan datangnya yai rutin tiap bulan..." (inf K7)

"supervisi dari dinas dengan jadwal yang tidak pasti, supervisi oleh bidan tiap pertemuan bu..." (inf K9)

$\begin{array}{lr}\text { Hasil } & \text { penelitian } \\ \text { menggambarkan } & \text { bahwa } \\ \text { supervisi dari dinas } & \text { kesehatan }\end{array}$

pada setiap wilayah kerja tidak dilakukan secara rutin. Hal ini didukung pernyataan dari informan yang menyatakan bahwa tenaga dari dinas kesehatan jarang melakukan supervisi ke desa dalam pelaksanaan P4K. Hal ini berdampak pada pelaksanaan kegiatan P4K yang tidak termonitor dengan baik khususnya oleh Dinas Kesehatan. Selain Dinas Kesehatan, Puskesmas juga mengadakan supervisi yang didelegasikan kepada bidan wilayah sehingga pelaksanaan P4K khususnya dalam pemberdayaan masyarakat tidak terkontrol oleh puskesmas. Hasil penelitian Azizah (2010) menyatakan bahwa kader akan melaksanakan perannya dalam desa siaga $\mathrm{P} 4 \mathrm{~K}$ secara maksimal jika ada pembinaan rutin dari Puskesmas dalam menjalankan program P4K. ${ }^{13}$

2) Dukungan organisasi pelaksana Dari hasil wawancara mendalam dengan informan utama didapatkan bahwa masyarakat dan perangkat mendukung kegiatan P4K. Informasi yang sama didapatkan dari informan triangulasi kader yang menyatakan bahwa masyarakat, perangkat desa dan kepala desa mendukung kegiatan $\mathrm{P} 4 \mathrm{~K}$ dan siap membantu program tersebut. Pernyataan informan penelitian terdapat pada kotak 18

Kotak 18

"Perangkat tidak begitu berperan sih bu karena semua dibebankan pada sektor kesehatan...." (Inf $\mathrm{KP})$

"Kepala desa dan masyarakat sangat mendukung kok bu...." (Inf K3)

“Sama mendukungnya...” (Inf 6)

"Puskesmas dan Dinas mewadahi saja dalam kegiatan ini..." (Inf KK) 
Notoatmodjo

(2007)

menyatakan bahwa partisipasi masyarakat akan terlaksana dengan baik jika adanya team work. Sesuai dengan prinsip pemberdayaan masyarakat, petugas atau provider dalam memberdayakan masyarakat adalah bekerjasama dengan masyarakat (work with the community). Oleh karena itu provider berperan dalam memfasilitasi, memotivasi dan mengalihkan pengetahuan, ketrampilan dan teknologi kepada masyarakat.

3) Koordinasi

Dari hasil wawancara mendalam dengan informan utama didapatkan informasi bahwa koordinasi dalam kegiatan $\mathrm{P} 4 \mathrm{~K}$ berjalan dengan lancar dari kader ke bidan, bidan ke lintas sektor, dan puskesmas ke dinas kesehatan. Hal ini sesuai dengan informasi yang didapatkan dari triangulasi yang menyatakan bahwa jalur koordinasi adalah dari kader ke bidan, bidan ke lintas sektor. Pernyataan informan penelitian terdapat pada kotak 20.

Kotak 20

"Ya kalau ada masalah langsung ke bidan, bidan lintas sektor, bidan ke puskesmas, puskesmas ke dinas." (Inf KK)

“ Jalur koordinasinya dari kader ke bidan wilayah, nanti kalau ada kesulitan bidannya menyampaikan ke Puskemas ..."(Inf KP)

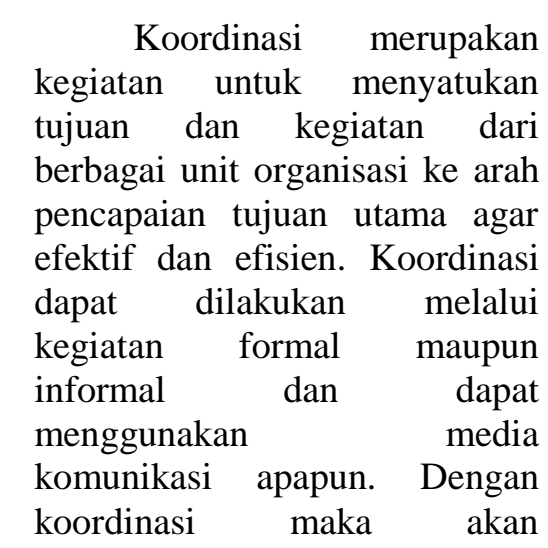

menghemat

pembiayaan, mencegah pemborosan, menghemat waktu, tenaga dan material. ${ }^{13}$

Adanya persamaan informasi tentang koordinasi dalam pemberdayaan masyarakat dalam kegiatan P4K yaitu dari kader ke bidan, bidan ke lintas sektor, puskesmas dan dinas kesehatan, dikarenakan jalur koordinasi sudah diketahui oleh seluruh komponen karena dipakai dalam semua program yang dijalankan oleh sektor kesehatan.

e. Sikap Para Pelaksana

1) Pengetahuan tentang Pemberdayaan Masyarakat dalam Kegiatan P4K Dalam wawancara mendalam yang dilakukan pada informan utama tentang sikap bidan dalam pelaksanaan $\mathrm{P} 4 \mathrm{~K}$ didapatkan hasil bahwa hampir seluruh informan utama menyatakan kegiatan P4K yang harus menjalankan adalah masyarakat, sedangkan bidan adalah sebagai fasilitator, motivator dan mitra saja. Ada satu bidan yang menyatakan bahwa P4K tidak hanya dijalankan oleh masyarakat namun harus ada andil dari Dinas Kesehatan juga. Pernyataan informan penelitian terdapat pada kotak 21 .

Kotak 21

"Yang menjalankan adalah masyarakat bidan dan kader adalah sebagai mitra " (Inf B3)

"Bidan memfasilitasi, kader pengelola dan masyarakat mendukung, perangkat diajak bekerjasama dan semua transparan...” (Inf B4)

"Memberdayakan masyarakat untuk bisa melaksana kan sendiri kegiatan $\mathrm{P} 4 \mathrm{~K}$, Bidan hanya memantau kalau bisa dinas kesehatan juga ikut terjun kelapangan gitu bu...” (Inf B6)

Sikap penerimaan atau penolakan dari agen pelaksana akan sangat banyak 
mempengaruhi keberhasilan atau tidaknya kinerja implementasi kebijakan. Tiga unsur tanggapan pelaksana yang mungkin mempengaruhi kemampuan dan keinginan untuk melaksanakan kebijakan yaitu kognisi (komprehensi, pemahaman) tentang kebijakan, macam tanggapan (penerimaan, netralitas, penolakan) dan intensitas tanggapan itu. ${ }^{12}$

Hal ini sesuai dengan prinsip pemberdayaan masyarakat dimana terdapat prinsip desentralisasi yaitu pengambilan keputusan ada pada masyarakat, sehingga peran petugas kesehatan hanya dalam batas sebagai fasilitator, motivator serta mengalihkan pengetahuan dan dan ketrampilan kepada masyarakat. ${ }^{14}$

Namun hal ini tidak sejalan dengan informan triangulasi yang menyatakan bahwa Program P4K merupakan kewajiban yang harus dilaksanakan oleh bidan Pernyataan informan penelitian terdapat pada kotak 22.

Kotak 22

"Memang itu sudah program, itu sudah jadi kewajiban yang harus dijalankan. Tidak ada kata menyerah buat kami. Ya sebisa mungkin saya akan bantu. Ya saya tahu itu kadang berat buat bidan karena beban kerja bidan banyak sekali, tetapi tetap harus jalan semua..." (Inf KP)

"Itu kan program nasional, mau tidak mau harus dijalankan. Komitmen jadi bidan ya harus menjalankan tugasnya secara maksimal. Kita dan puskesmas pastinya akan membantu jika ada kesulitan di wilayah. Memang berat tugasnya, tapi ya namanya juga pengabdian..." (Inf KK)

\section{Menurut Bloom,}

dikatakan bahwa pengetahuan merupakan domain penting dalam membentuk tindakan seseorang. Dari pengalaman dan penelitian terbukti bahwa perilaku yang didasari oleh pengetahuan akan lebih langgeng daripada perilaku yang tidak didasari oleh pengetahuan. Bila penerimaan perilaku didasari oleh pengetahuan, kesadaran dan sikap yang positif maka perilaku tersebut akan bersifat langgeng (long lasting). ${ }^{14}$ Hal tersebut dikuatkan dengan prinsip dalam manajemen kebijakan yang menyatakan bahwa penerimaan atau penolakan terhadap suatu kebijakan salah satunya dipengaruhi oleh pemahaman seseorang terhadap kebijakan tersebut. ${ }^{12}$

2) Respon Puskesmas dan Dinas Kesehatan terhadap tugas Bidan Hasil wawancara mendalam terhadap informan utama didapatkan informasi bahwa Informan utama menyatakan tanggapan Dinas Kesehatan dan Puskesmas menganggap bahwa ini adalah program nasional yang harus dijalankan oleh bidan dan masyarakat.

Sejalan dengan informasi yang diperoleh dari informan utama, informan triangulasi dari Dinas Kesehatan dan Kepala Puskesmas menganggap bahwa ini adalah program nasional yang harus dijalankan oleh bidan dan masyarakat walaupun berat. Hal tersebut terdapat pada kotak 22. Sehingga hal tersebut berdampak pada bidan dan kader mempunyai tugas yang berat untuk terus memberdayakan masyarakat agar P4K tetap berjalan.

f. Komunikasi dalam mendukung pelaksanaan $\mathrm{P} 4 \mathrm{~K}$

1) Sosialisasi

Dari hasil wawancara mendalam terhadap informan utama didapatkan informasi bahwa Seluruh Informan Utama menyatakan bahwa ada sosialisasi dari bidan untuk kader dan dari Dinas Kesehatan 
untuk bidan. Hal ini sejalan dengan informasi yang didapatkan dari seluruh informan triangulasi Kader yang menyatakan bahwa sosialisai P4K diberikan oleh bidan saat ada kegiatan kelas ibu hamil dan Posyandu. Pernyataan informan penelitian terdapat pada kotak 25.

Kotak 25

"Posyandu ada sih bu." (Inf K3)

"Sosialisasinya sama kader-kader saat ada kegiatan kelas ibu hamil sama posyandu bu.." (Inf K9)

"Biasanya ada di kelas ibu hamil sama ibu hamilnya juga kadang suaminya juga ikut..” (Inf K4)

Pembangunan di sektor

kesehatan tidak akan berjalan dengan baik dan efektif tanpa adanya proses komunikasi. Komunikasi bukan saja diperlukan untuk melibatkan seluruh komponen masyarakat agar berpartisipasi dalam pembangunan kesehatan, tetapi juga diperlukan untuk memperoleh dukungan politik dan kebijaksanaan dari para pejabat penyelenggara negara/pemerintah. ${ }^{13}$

Untuk penyebarluasan kegiatan $\mathrm{P} 4 \mathrm{~K}$ sampai tingkat operasional, di tingkat kabupaten dilakukan pemberian informasi dan penyamaan persepsi bagi dokter dan bidan puskesmas termasuk lintas sektor dan lintas program. Sedangkan orientasi di tingkat desa dilakukan pemberian informasi dan penyamaann persepsi bagi kepala desa dan tokoh masyarakat yang berpengaruh serta kader kesehatan. $^{9}$

Hasil penelitian menunjukkan kesesuaian antara teori dengan pelaksanaan di lapangan bahwa sebelum dilaksanakan program $\mathrm{P} 4 \mathrm{~K}$, di tingkat kabupaten telah dilaksanakan sosialisasi kegiatan kepada bidan wilayah dan kader kesehatan. Dan dalam operasional $\mathrm{P} 4 \mathrm{~K}$ di tingkat desa dilaksanakan sosialisasi oleh bidan desa dengan memanfaatkan pertemuan bulanan tingkat desa. ${ }^{9}$

2) Bentuk Komunikasi

Dari hasil wawancara mendalam terhadap informan utama didapatkan informasi bahwa hampir seluruhnya menyatakan bahwa bentuk komunikasi dalam kegiatan P4K melalui pertemuan kelas Ibu hamil, pertemuan kader maupun Posyandu.

Hal ini sejalan dengan informasi dari informan triangulasii yang menyatakan bahwa seluruhnya informan triangulasi kader menyatakan bahwa bentuk komunikasi lewat pertemuan kader setiap bulan. Ada juga kader yang berpendapat bahwa komunikasi juga dilaksanakan melalui posyandu dan PKK. Pernyataan informan penelitian terdapat pada kotak 27

Kotak 27

"Ada di Pertemuan posyandu dan kader.." (Inf K1, K2, K3,K5, K6, K7, K8)

"Biasa lah bu pertemuan itu ada saat pertemuan kader, PKK, Pengajian...'(Inf K4, K9

Bidan dapat melaksanakan komunikasi dengan kader dalam kegiatan $\mathrm{P} 4 \mathrm{~K}$ melalui kegiatan posyandu, kelas Ibu hamil atau kunjungan rumah. $^{2}$ Dalam konsep komunikasi, teknik dalam melaksanakan komunikasi dan koordinasi dapat dilakukan dalam bentuk formal maupun non formal, bahkan dapat menggunakan alat komunikasi seperti telepon. ${ }^{15}$

Hasil penelitian yang menunjukkan bahwa kegiatan tabulin tidak berjalan dengan baik salah satunya dikarenakan bentuk komunikasi yang dijalankan tanpa media khusus seperti brosur dan leaflet 
sehingga informasi yang diterima kurang diingat oleh kader dan masyarakat.

3) Konsistensi

Dari hasil wawancara mendalam didapatkan informasi bahwa Seluruh Informan Utama menyatakan setiap pertemuan kader selalu disinggung tentang informasi P4K. Senada dengan hal tersebut, seluruh informan triangulasi kader juga menyatakan bahwa konsistensi komunikasi dalam kegiatan P4K selalu disampaikan saat pertemuan kader.

$$
\text { Dalam }
$$

konsep pemberdayaan masyarakat dikatakan bahwa bidan mempunyai peran dan ketrampilan yang salah satunya berupa ketrampilan edukasi. Ketrampilan edukasi yang dimaksudkan adalah membangkitkan kesadaran masyarakat, menyampaikan informasi, dan pelatihan. Dalam ketrampilan penyampaian informasi, konsistensi mutlak diperlukan karena pesan akan bersifat menonjol bila intensitasnya diulang-ulang sehingga pelaksanaan suatu kebijakan akan dapat dilaksanakan secara kontinyu. ${ }^{14}$

g. Kondisi Ekonomi dan Sosial

1) Kondisi Ekonomi

Sebagian besar informan utama menyatakan bahwa status ekonomi masyarakatnya sebagian besar menengah dan menengah ke bawah. Sejalan dengan informasi dari informan utama, sebagian besar informan triangulasi kader juga menyatakan bahwa status ekonomi dari kalangan menengah. Kondisi sosial ekonomi bagus tetapi tabulin sulit digerakkan. Pernyataan informan penelitian terdapat pada kotak 31 .
Kotak 31

"Kondisi menengah itu biasanya nabung sendiri bu..." (Inf K1)

"Ada dua golongan itu menengah ke bawah dan menengah sehingga tabulin tidak jalan.." (Inf K5)

"Daerah minus, kegiatan yang memerlukan dana sulit berjalan walaupun sudah diberi contoh ..." (Inf K3)

$\begin{array}{cr}\text { Lingkungan } & \text { eksternal } \\ \text { yang } & \text { kondusif }\end{array}$ mempengaruhi keberhasilan suatu kebijakan. Lingkungan ekonomi yang tidak baik akan menjadi suatu kegagalan dalam kinerja. $^{10}$ Sedangkan dalam kegiatan ini diperlukan dukungan masyarakat dalam menggunakan sumberdaya yang ada termasuk dukungan dana.

Pemberdayaan

masyarakat pada hakikatnya adalah menggali potensi masyarakat terutama potensi ekonomi. Hal ini dimaksudkan agar masyarakat berkontribusi sesuai dengan kemampuan terhadap program yang dijalani. $^{13}$

Kondisi ekonomi masyarakat sedikitnya akan mempengaruhi masyarakat dalam berpartisipasi terhadap kegiatan. Namun kegiatan yang terhambat seperti tabulin tidak dapat berjalan bukan hanya karena status ekonominya tetapi maraknya jaminan kesehatan yang ada di masyarakat menghambat partisipasi masyarakat dalam kegiatan tersebut.

2) Kondisi Sosial

Seluruh informan utama menyatakan bahwa kondisi sosial masyarakat mendukung kegiatan $\mathrm{P} 4 \mathrm{~K}$ kerena banyak manfaat bagi mansyarakat. Sejalan dengan pernyataan informan utama, seluruh informan triangulasi kader 
menyatakan bahwa kondisi sosial tentang kegiatan $\mathrm{P} 4 \mathrm{~K}$ mendukung program $\mathrm{P} 4 \mathrm{~K}$.

Suatu program kesehatan apapun hendaknya memperoleh dukungan dari sasaran utamanya yaitu masyarakat terutama tokoh masyarakat. Dengan adanya dukungan dari masyarakat berarti diterimanya suatu program kesehatan oleh masyarakat. ${ }^{13}$

\section{Simpulan}

a. Kegiatan bidan dalam mendukung kegiatan P4K yang belum berjalan adalah donor darah dan tabulin. Beberapa alasan yang menjadi penyebabnya adalah karena belum banyak ibu hamil yang mengetahui golongan darah dan masih sulitnya mengetahui keluarga yang mempunyai golongan darah yang sama. Kesulitan dalam adanya Tabullin karena masyarakat dan Ibu hamil masih mengandalkan Kartu BPJS, Jamkesmas dan Jampersal khususnya untuk masyarakat miskin. Upaya untuk memandirikan masyarakat terganjal banyaknya jaminan kesehatan yang bisa didapatkan dengan mudah. Selain itu, jampersal tidak hanya berlaku di institusi pelayanan kesehatan pemerintah tetapi juga di institusi pelayanan kesehatan swasta yang mengikuti program jampersal

b. Ukuran dasar dan tujuan kebijakan

Tidak ada aturan yang jelas tentang kegiatan pemberdayaan masyarakat yang tertuang dalan ukuran dasar dan tujuan kebijakan dalam menggalang tabulin.

c. Sumberdaya

Sumber daya manusia yang ada dalam pemberdayaan masyarakat sudah sesuai yaitu bidan melibatkan kader dalam menjalankan P4K .

d. Karakteristik pelaksana P4K

Tidak semua bidan dan kader mendapatkan pelatihan dan informasi dari Dinas Kesehatan tentang pelaksanaan $\mathrm{P} 4 \mathrm{~K}$ termasuk dalam penggerakan tabulin. Selain itu, tidak semua bidan melakukan pembinaan dalam kegiatan pemberdayaan masyarakat khususnya dalam kegiatan tabulin. Puskesmas mendelegasikan kepada bidan wilayah setempat, dinas kesehatan kurang melakukan melakukan kontrol dalam setiap kegiatan P4K.

e. Sikap para pelaksana

Semua bidan tidak merasa terbeban dengan tanggungjawabnya dalam menjalankan kegiatan pemberdayaan masyarakat khususnya tabulin sebagai salah satu kegiatan dalam P4K. Namun bidan kurang memberi informasi yang jelas kepada masyarakat tentang maksud, tujuan dan manfaat tabulin karena sebagian besar masyarakat menggunakan sarana BPJS dan Jamkesmas.

f. Komunikasi

Sosialisasi yang dilaksanakan oleh DKK kepada bidan wilayah dan kader hanya dilaksanakan setiap 1 tahun sekali dalam bentuk penyegaran dan hanya diwakili beberapa orang. Tidak ada forum pertemuan khusus tentang pelaksanaan P4K, Sosialisasi hanya dilakukan dalam pertemuan Kelas Ibu Hamil maupun posyandu. Selain itu, komunikasi hanya berupa pendidikan kesehatan dan tanya jawab serta tidak ada media khusus yang digunakan dalam penyampaian informasi.

g. Kondisi ekonomi, sosial dan politik

Kondisi masyarakat dengan tingkat ekonomi masyarakat dalam strata menengah dan menengah kebawah tidak mempengaruhi kegiatan P4K karena banyaknya jaminan kesehatan yang diandalkan oleh masyarakat. Namun pihak terkait masih perlu mengimbangi dengan usaha penggerakan masyarakat khususnya tabulin. 


\section{Daftar Pustaka}

[1] Kementerian kesehatan. Mengurangi Angka Kematian Ibu Melahirkan (AKI). (editorial). 2017. Diakses dari : http://www.menegpp.go.id.

[2] Dinkes Kabupaten Pekalongan. Profil Kesehatan Tahun 2018. Dinkes Kabupaten Pekalongan. 2018.

[3] Dinkes Kabupaten Pekalongan Laporan KIA (Pelaksanaan P4K) tahun 2018. Dinkes Kabupaten Pekalongan.

[4] Depkes RI. Program Safe Motherhood di Indonesia. Depkes RI, Jakarta. 2002 : $15,21$.

[5] Depkes RI. Materi KIE Safe Motherhood "Making Pregnancy Safer". Depkes RI, Jakarta. 2004 : 1-4.

[6] Depkes RI. Materi Ajar Penurunan Kematian Ibu dan Bayi Baru Lahir. Depkes RI, Jakarta. 2006 : 43-46.

[7] Annonymous. Menkes Canangkan Stiker Perencanaan Persalinan dan Pencegahan Komplikasi.(editorial). 2007. Diakses dari http://www.puskom.publik.com.

[8] Kementrian Kesehatan RI. Rencana Strategis Kementrian Kesehatan Tahun 2010 - 2014 (Kepmenkes RI no. HK.03.01/160/I/2010). Jakarta, 2010.

[9] Depkes RI. Pedoman Praktis Program Perencanaan Persalinan dan Pencegahan Komplikasi (P4K) dengan Stiker. Depkes RI, Jakarta. 2007 : 1-4.

[10] Nugroho, Riant. Public Policy. PT Elex Media Komputindo, Jakarta. 2008 : 429470

[11] Winarno, Budi. Kebijakan Publik: Teori dan Proses. Med Press, Yogyakarta. $2008: 143-224$.

[12] Agustino, Leo. Dasar-dasar Kebijakan Publik. Alfabeta, Bandung. 2008 : 138165.

[13] Nurazizah, Retno. Hubungan Persepsi dan motivasi kader kesehatan dengan kinerja dalam Desa Siaga Program Perencanaan Persalinan dan Pencegahan Komplikasi. Tesis. 2010. Diakses dari : http://pasca.uns.ac.id.

[14] Darmining. Faktor-Faktor Yang Mempengaruhi Keberhasilan Penerapan Program Perencanaan Persalinan dan Pencegahan Komplikasi (P4K) Dalam
Menurunkan Angka Kematian Ibu. Tesis. 2010 Diakses dari : http://pasca.uns.ac.id.

[15] Satrianiaga, Fais. Buku Ajar Organisasi dan Manajemen Pelayanan Kesehatan serta Kebidanan. Salemba Medika, Jakarta. 2009. 